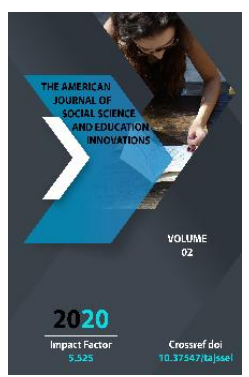

\title{
Conclusion And Registration Of Contracts In The Field Of Telecommunication Services
}

Journal Website: http://usajournalshub.c om/index,php/tajssei

Niholbek Ganiev

PhD candidate at the Tashkent State University of Law, Uzbekistan.

\section{ABSTRACT}

This article provides a legal analysis of the procedure for concluding and registration of contracts in the field of telecommunication services. It presents the author's approach on the appropriateness of liberalizing to a certain extent the practice of defining the process of conclusion and execution of contracts on the provision of telecommunication services by regulatory acts, as well as determining the rules on the procedure for concluding an agreement at the legislative level.

\section{KEYWORDS}

Telecommunications, data transfer, paid services contract, public offer.

\section{INTRODUCTION}

A contract for telecommunications services is, of course, one of the types of contracts for the provision of services against payment. However, in the Chapter 38 of the Civil Code of the Republic of Uzbekistan there are no provisions on the procedure how to conclude the contract for paid services or specific rules how to deal with its important conditions. In addition, the Civil Code does not define the rules on the procedure for concluding a contract for the provision of paid services in the field of communications, which is a type of paid services. It is obvious that the contract for the provision of telecommunications services is concluded on the basis of two-tier norms. [1] The first level includes the general rules of contracts specified in the Civil Code, which set out the basic principles for concluding any contract, regardless of their content. The second level implies special rules for concluding telecommunications contracts, provided for by the legislation in the field of telecommunications. 
As in the case of any contract, the conclusion of contracts for the provision of telecommunications services is based on the general rules of civil law. In accordance with the provisions of Chapter 27 of the Civil Code on the conclusion of contracts, the practice of concluding contracts is applied based on the specifics of contracts for telecommunications services. It is known that the procedure for concluding this type of agreement is determined by the status of users of telecommunications services. In the event that telecommunications services are provided to citizens who have entered into an agreement in the form of a public offer as consumers, this document must be drawn up on the basis of the requirements of the public agreement provided for in Article 358 of the Civil Code, in accordance with the procedure of Article 369 of the Civil Code. According to Article 369 of the Civil Code, an offer to conclude a contract is sent to an indefinite number of persons in the form of advertising or otherwise, in which case the offer is considered an offer. Of course, such an offer can only be made in the form of advertising, and in this case it will not be considered as an offer. For example, if a telecommunication company announces that in a pandemic it is convenient to connect customers to a particular network, and that in this case they will be provided with deductions from payments, then this will be an advertisement, not an offer. For such a case to be an offer, a clear indication of the names and addresses of the companies that provide the relevant telecommunications services is required. As examples of a proposal, an offer can be called advertising, distribution of catalogs, price lists, booklets, product samples and other offers sent to anonymous individuals. [2]

In this case, it is necessary to distinguish between an offer and a public offer. In the case of a public offer, the law provides for the need to indicate the main terms of the contract and the requirement of the readiness of the person who submitted this offer to conclude an agreement with any other person who has approached him with such readiness. For example, in the case when a telecommunications network offers to connect a subscriber to a network by a mobile operator in an advertisement for certain persons, and also indicates the types of services provided and their prices, then this is a public offer. In this case, the telecommunications organization does not have the right to refuse to conclude an agreement with a citizen who made such a request. So, according to the Rules "Provision of telephone services in the field of public telecommunications" (registration number 1323 of 03/15/2004), the telecom operator does not have the right to refuse to accept a citizen's application to conclude an agreement. According to clause 21 of these Rules, in the case of a request from an individual, the telecom operator must satisfy him if the applicant has submitted a document confirming his identity, as well as his permanent or temporary registration at the specified address (registered at the place of residence) or a document confirming him the right to real estate.

The telephone service agreement is public and is concluded when technically possible. The applicant, presented as a party to the contract, has the status of a signatory. The subscriber's number allocated at the conclusion of the contract is entered into the database of the information service of the telecom operator. At the request of the subscriber, his number can be removed from the information service operator's database. The contract between the subscriber and the telecom operator is considered indefinite, unless otherwise provided by the contract. The lack of technical ability to conclude an 
agreement with an individual is not an obstacle to concluding an agreement with another individual who has such (technical) ability and who submitted an application later. According to the current legislation, for certain categories of citizens, officials, organizations, in accordance with the legislation, priorities can be established in terms of the procedure for providing access to the telecommunications network and the procedure for using services. The list of certain categories of citizens, officials, organizations is determined by the Cabinet of Ministers of the Republic of Uzbekistan.

According to R.Kh. Khursanov, the fact that the contract for the provision of telephone services is a public contract does not allow the service provider, if it is possible to provide these services to the consumer-subscriber, to refuse to conclude a public contract, otherwise, in accordance with Article 377 of the Civil Code, the second party has the right go to court with a claim for coercion to conclude an agreement, and as a result, a party that unreasonably refuses to conclude an agreement will have to compensate the other party for the damage caused. [3]

By acceding to this provision, the refusal of the telecommunications organization to conclude an agreement for the provision of telecommunications services gives the second party the right to file a claim for the compulsory conclusion of the agreement and compensation for losses caused by the party unreasonably refusing to conclude the agreement (parts 6-7, article 377, Civil Code Republic of Uzbekistan).

Contracts for the provision of telecommunications services can be classified as interconnection contracts. This is due to the fact that in such contracts, standard terms of the contract are developed by telecommunications companies. According to the first part of Article 360 of the Civil Code, an accession agreement is an agreement in which one party defines the conditions in forms or other standard forms, and the other party only accepts the proposed agreement in full.

A telecommunications service agreement, such as a telephone service agreement, can be concluded by completing an application form in a standard form .

In accordance with the current legislation, the conditions for the provision of telecommunications services, including a contract for telephone services, can be presented in simple written form (2 copies, 1 copy is provided to the subscriber, the other remains with the operator) or by performing implicit actions.

The conclusion of an agreement for the provision of telecommunications services by means of conclusive actions is usually applied when using appropriate payment cards and when providing one-time services. The transfer of funds by a client to a telecommunications service provider under an agreement for the purpose of concluding an agreement is considered an acceptance of an offer for concluding an agreement.

As a rule, the conclusion of a contract for the provision of telecommunications services in writing can be divided into several stages. At the first stage, any person wishing to arrange a telecommunications service must submit an application to the operator to conclude a contract. In this case, the application is considered in accordance with the established procedure, and appropriate negotiations can be conducted to conclude a written agreement with the client. For example, in the course of such negotiations, it may be revealed that the client has the conditions for the installation of appropriate equipment to receive telecommunication services, or special conditions of the client's area of residence may be determined. In particular, when a 
client connects to the Internet and provides him with the appropriate megabytes for using the Internet, the terms of providing services to the client may be determined depending on the availability of the Internet provider's point of contact in the client's area of residence. In accordance with paragraph 18 of the Rules "Provision of telephone services in the field of public telecommunications", an application for the conclusion of a contract may be submitted:

- $\quad$ An individual who, in accordance with the law, is able-bodied, permanently registered at the place of residence or the owner or tenant of this place of residence;

- $\quad$ A legal entity registered by the state in the manner prescribed by law, as well as its branch or representative office.

- With the written consent of the parents, adoptive parents or guardians, an application can be submitted by a person who has reached the age of sixteen. [4]

At the second stage, the telecommunications organization checks that the applicant has the appropriate technical equipment capable of receiving telecommunications services. At the third stage, a contract for the provision of telecommunications services is signed with the client , and thus the applicant is connected to the telecommunication services network of his choice.

In accordance with the Regulation "On the transmission and distribution of TV and radio broadcasting programs in the Republic of Uzbekistan" (registration number 1409 dated September 15, 2004), broadcasting of TV and radio broadcasting programs is carried out in the manner prescribed by law. For this, it is necessary that the technical means of transmission and distribution of television and radio broadcasting programs belong to the performer, as well as these means must be subject to mandatory certification and have a certificate of ownership in the manner prescribed by law. In this case, the contractor must also have an appropriate permit to operate technical equipment on a specific radio wave.

The customer may apply to the contractor in order to conclude an agreement on the transmission and distribution of television and radio programs, as well as with a request to the contractor to provide preliminary conditions for the contract until the customer receives a certificate of registration of the media and a license for this activity. The contractor must declare his consent to the conclusion of the contract within 30 days from the date of receipt of the application from the customer or send him a notification about the conclusion of the contract on other conditions indicating the characteristics of the technical equipment for which the customer needs to purchase a license. After the conclusion of a bilateral agreement, the customer can receive services for the transmission and distribution of TV and radio broadcasting programs in the manner prescribed by law.

An agreement for the transmission of television and radio programs is concluded by submitting an offer to conclude a document by one party, and by accepting the offer by the other. The conclusion of such an agreement is carried out after the customer receives a certificate of media registration and a license for this activity. In this case, the customer must obtain a copy of the contractor's license and the contractor must receive a copy of the customer's license.

To conclude an agreement for the transmission and distribution of television and radio programs, the customer must provide the contractor with the following documents: a copy of the license, a copy of the mass media registration certificate, a list of persons entitled to use the technical means of 
transmission and distribution of television and radio broadcasting programs with their passport data attached, a monthly download schedule channels for the transmission and distribution of television and radio programs, approved by the customer, the list of equipment for the transmission of television and radio signals, including the contractor's technical means, as well as information on their technical parameters.

The contract comes into force on the day it is signed by the customer and the contractor and is binding on both parties. The parties may determine that the terms of the agreement concluded by them may apply to the relations that arose between them before the conclusion of the agreement.

As a rule, the contract for the transmission and distribution of television and radio programs is concluded for a period not exceeding the term of the license of the customer and the contractor. In case of renewal of this license, by agreement of the parties, the contract can be extended for the period of validity of the new license. This agreement must indicate the type of equipment, the number and duration of channels, the average daily load, the annual cost of services (including quarterly), the percentage of advance payments, as well as other information related to the provision of services for the transmission and distribution of television and radio programs.

\section{CONCLUSION}

In conclusion, I would like to note that it is deemed appropriate to liberalize to a certain extent the practice of defining by-laws the process of concluding and executing an agreement for the provision of telecommunications services, as well as to determine the rules on the procedure for concluding an agreement at the legislative level. In addition, in view of the breadth and diversity of the system of telecommunication networks and contracts for the provision of this service, it is necessary to simplify the procedure for concluding such contracts.

\section{REFERENCES}

1. Chaynikov I.V. Contract of paid services for telephone network: abstract ... Doctor of philosophy. - M.: 2007. - 22 page.

2. Comment to the Civil code of the Republic of Uzbekitan. I-volume. Tashkent: Vektor-Press, 2010. - 492-493 pages.

3. Khursanov R.X. Features of legal regulation of telephone services: Doctor of philosophy dissertation. - Tashkent: 2011. - 118 page.

4. Collection of legal acts of the Republic of Uzbekistan, 2004, volume No.11, article 130. 